mgr inz. Tomasz Gazdulski

Instytut Pojazdów Szynowych ,TABOR”

mgr inz. Julian Kominowski

mgr inz. Mateusz Motyl

Politechnika Poznańska

\title{
Eksperymentalna weryfikacja ograniczeń prędkości jazdy lekkich pojazdów szynowych $w$ aspekcie przyjętych wskaźników bezpieczeństwa
}

\begin{abstract}
W niniejszym artykule dokonano konfrontacji odpowiedzi dynamicznej miejskiego lekkiego pojazdu szynowego podczas normalnej eksploatacji na wybranych odcinkach infrastruktury tramwajowej. Opisano cele i metodyke przeprowadzonych eksperymentów oraz przedstawiono ich zakres. Zaproponowano metodę sprawdzenia ograniczeń prędkości na podstawie których przewoźnik lub zarzq̨dca infrastruktury będzie mógt poddawać weryfikacji zatożonych ograniczeń prędkości, bezpośrednio wpływajac na komfort i bezpieczeństwo jazdy.
\end{abstract}

\section{Wstęp}

Kongestia ruchu pojazdów szynowych na sieciach komunikacyjnych miasta naturalnie prowadzi do zwiększonej degradacji infrastruktury. W wyniku oględzin prowadzonych przez toromistrzów lub diagnostów odpowiedzialnych za stan techniczny z ramienia zarządcy infrastruktury, wprowadzane są, na jej odcinkach, ograniczenia prędkości, wynikające z procesu degradacji, często nie zmieniając rozkładu jazdy. Działanie takie prowadzi do powiększenia problemu poprzez destabilizację rozkładowego ruchu pojazdów szynowych. Biorąc pod uwagę rozwój systemów diagnostycznych oraz ich zastosowanie w ocenie stanu technicznego pojazdów i toru, podjęto się próby weryfikacji założonych ograniczeń prędkości ze stanem technicznym infrastruktury. Do weryfikacji użyto wyników pomiarów przyspieszeń drgań poprzecznych i pionowych zarejestrowanych na łożyskach osi tocznych, jakościowo określające stan techniczny toru z pozycji eksploatowanego pojazdu szynowego [3].

\section{Metodyka pomiarów}

W ramach Projektu MONIT prowadzonego w latach 2008-2013, finansowanego z Programu Operacyjnego Innowacyjna Gospodarka, utworzony został system monitorowania stanu technicznego pojazdu oraz jakościowej oceny stanu toru [1]. W skład systemu monitorowania wchodzą trzy podsystemy: pokładowy (umieszczony na pojeździe), serwera i przetwarzania danych oraz podsystem użytkownika aplikacja.

Obecnie system zamontowany jest na kilku pojazdach szynowych używanych przez Miejskie Przedsiębiorstwo Komunikacyjne w Poznaniu. Do badań wykorzystano wyniki pomiarów przyspieszeń drgań pionowych i poprzecznych pochodzacych $z$ prawego łożyska osi atakującej tramwaju Moderus Alfa.

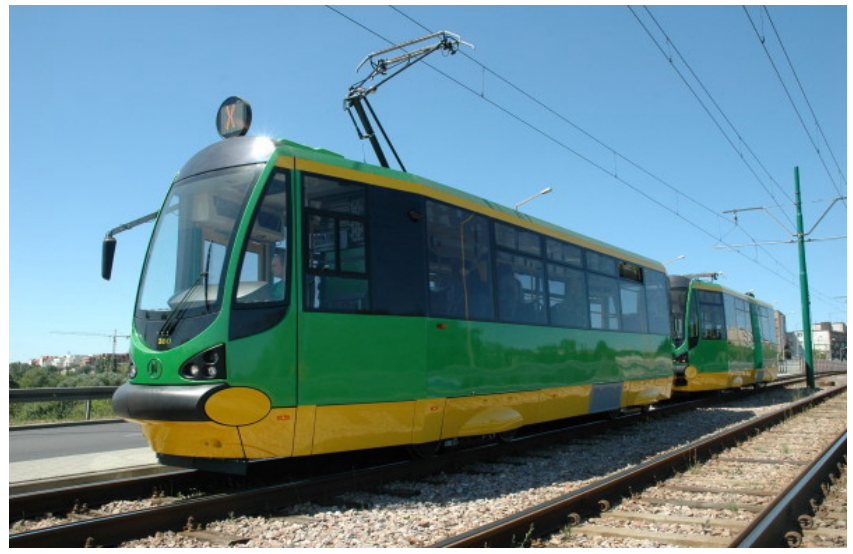

Rys.1. Moderus Alfa [8]

\subsection{Odcinki pomiarowe}

Do badań wybrano dwa odcinki poznańskiej infrastruktury tramwajowej mieszczące się między przystankami Serafitek - Rondo Rataje oraz Rondo Starołęka - Rondo Żegrze. Obydwa odcinki stanowią wydzielone torowiska na których obowiązuja różne ograniczenia prędkości jazdy. Pierwszy obszar pomiarowy stanowi droga o odległości między przystankami ok. $350 \mathrm{~m}$. W odległości ok. $10 \mathrm{~m}$ za przystankiem początkowym znajduje się równoległe skrzyżowanie drogowe oraz piesze. W czasie pomiarów na wybranym odcinku obowiązywało stałe ograniczenie prędkości do $30 \mathrm{~km} / \mathrm{h}$ wprowadzone przez Miejskie Przedsiębiorstwo Komunikacyjne ze względu na stan techniczny toru.

Drugim odcinkiem wykorzystanym do badań jest trasa pomiędzy przystankami Rondo Starołęka Rondo Żegrze o długości około $800 \mathrm{~m}$. Torowisko na całym swoim odcinku nie krzyżuje się z ruchem drogowym i pieszym. W obu kierunkach obowiązuje ograniczenie prędkości jazdy do $60 \mathrm{~km} / \mathrm{h}$. 


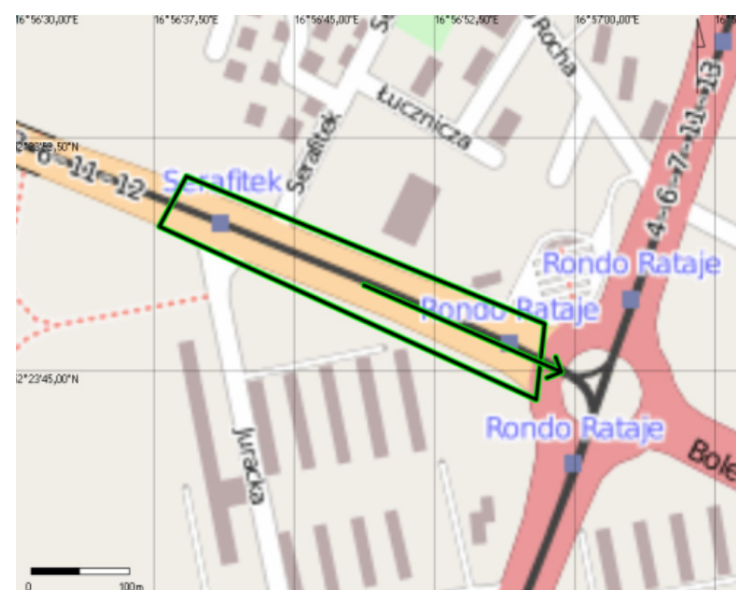

Rys. 2. Odcinek pomiarowy Serafitek - Rondo Rataje

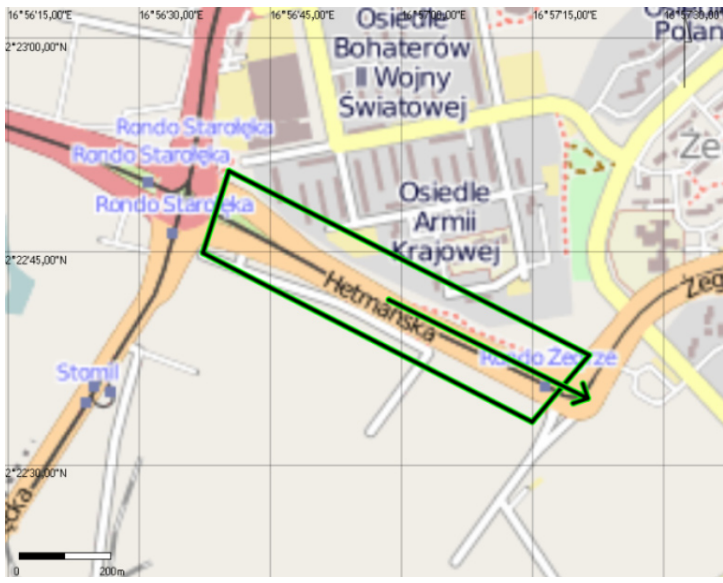

Rys. 3. Odcinek pomiarowy Rondo Starołęka - Rondo Żegrze

\section{Wyniki pomiarów}

\subsection{Prędkości}

\section{a) Odcinek pomiarowy Serafitek - Rondo Rataje}

$\mathrm{Na}$ odcinku pomiarowym zmierzono prędkości sześciu przejazdów tramwajem Moderus Alfa w pięciodniowym odstępie czasowym, przy podobnej temperaturze i ciśnieniu powietrza. Badania przeprowadzano przy podobnej ilości pasażerów. Do analiz wzięto pod uwagę następujące przejazdy:

- Przejazd $1 \mathrm{z}$ dnia 21.04.2013r., godzina 6:06.

- Przejazd 2 z dnia 19.04.2013r., godzina 8:56.

- Przejazd 3 z dnia 19.04.2013r., godzina 14:14.

- Przejazd 4 z dnia 21.04.2013r., godzina 13:47.

- Przejazd 5 z dnia 24.04.2013r., godzina 10:41.

- Przejazd 6 z dnia 24.04.2013r., godzina 12:16.

Poniżej przedstawiono wykres ukazujący prędkości tramwajów uzyskiwane na danym odcinku. Warto zwrócić uwagę, iż wszystkie tramwaje znacznie przekraczały dopuszczalne ograniczenie prędkości $(30 \mathrm{~km} / \mathrm{h})$.

b) Odcinek pomiarowy Rondo Starołęka Rondo Żegrze

$\mathrm{Na}$ drugim, odcinku badawczym zebrano i przeanalizowano wyniki badań pochodzące z przejazdów:

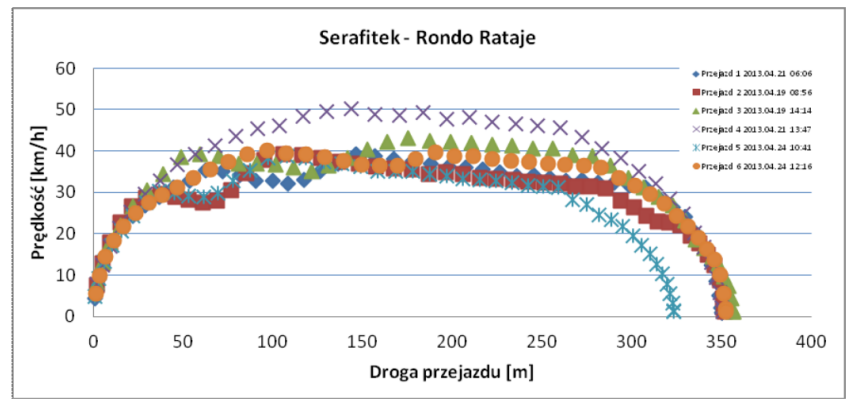

Rys.4. Prędkości tramwaju Moderus Alfa uzyskiwane na odcinku Serafitek - Rondo Rataje

$\mathrm{Na}$ drugim, odcinku badawczym zebrano i przeanalizowano wyniki badań pochodzące z przejazdów:

- Przejazd 1 z dnia 10.04.2013r., godzina 9:01.

- Przejazd 2 z dnia 10.04.2013r., godzina 14:55.

- Przejazd 3 z dnia 19.04.2013r., godzina 10:17.

- Przejazd 4 z dnia 19.04.2013r., godzina 12:53.

- Przejazd 5 z dnia 19.04.2013r., godzina 18:17.

- Przejazd 6 z dnia 21.04.2013r., godzina 19:36.

Rysunek nr 5 przedstawia przejazdy na odcinku Rondo Starołęka - Rondo Żegrze ukazując otrzymywane prędkości podczas poszczególnych przejazdów $\mathrm{w}$ funkcji drogi. $\mathrm{W}$ wybranych przejazdach maksymalna osiagana prędkość oscyluje wokół $60 \mathrm{~km} / \mathrm{h}$. Wspólną cechą wszystkich przejazdów jest utrzymywanie prędkości zgodnie $\mathrm{z}$ obowiązującym ograniczeniem na tym odcinku, które zostało podniesione i obecnie wynosi $60 \mathrm{~km} / \mathrm{h}$. Podniesienie ograniczenia prędkości, przez zarządcę infrastruktury, z $50 \mathrm{~km} / \mathrm{h}$ do $60 \mathrm{~km} / \mathrm{h}$ zostało wprowadzone ze względu na dobry stan techniczny toru.

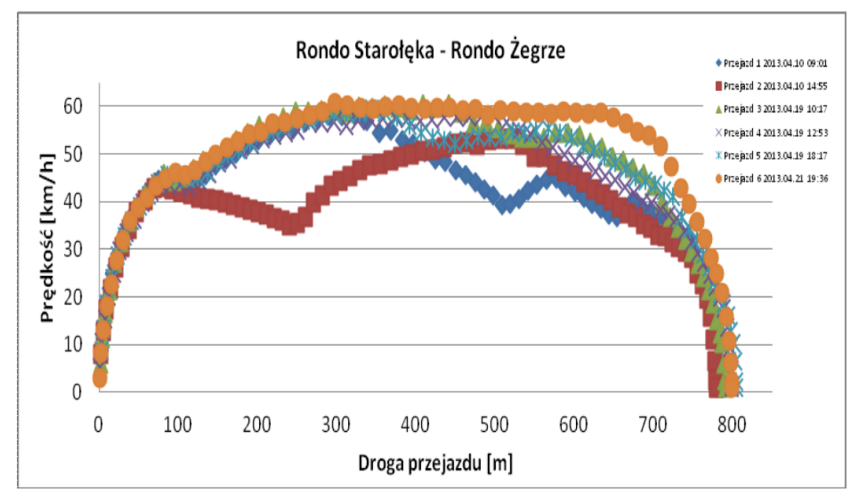

Rys.5. Prędkości z przejazdów tramwaju Moderus Alfa uzyskiwane na odcinku Rondo Starołęką - Rondo Żegrze

\subsection{Drgania pionowe}

Zebrane wyniki pokazano w postaci wykresów na których porównano skuteczne wartości przyspieszeń drgań pionowych względem drogi oraz prędkości tramwaju. 


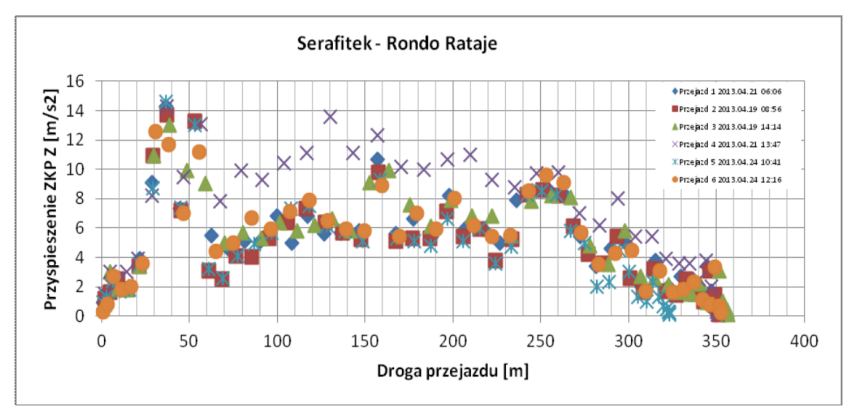

Rys. 6. Skuteczne wartości przyspieszeń w osi Z uzyskiwane na zestawie kołowym prawym (ZKP) na odcinku pomiarowym wraz z prędkościami

Na rysunku nr 6 zobrazowano nagły wzrost przyspieszeń przy wszystkich przejazdach w odległości ok. 50m od przystanku. Kolejna zauważoną zależnością jest związek pomiędzy prędkością przejazdu a uzyskiwanymi wynikami pomiarów. Tramwaj w czasie czwartego przejazdu wyraźnie poruszał się szybciej od pozostałych, analogicznie zmierzone wartości wyższe, w porównaniu do pozostałych pomiarów. Grupy punktów w okolicy 150 i 250 m również sugerują nierówności toru, co zostało potwierdzone podczas inspekcji odcinka.

W czasie czwartego przejazdu tramwaj poruszał się z prędkością ok. $45-50 \mathrm{~km} / \mathrm{h}$. Wzrost prędkości $\mathrm{w}$ porównaniu do pozostałych przejazdów miał wpływ na ukazanie wyników jako oddzielnej grupy z wyższymi wartościami przyspieszeń. Autorzy na wykres nałożyli wielomianową linię trendu dla każdego przejazdu jak i zbiorczą (rys.7).

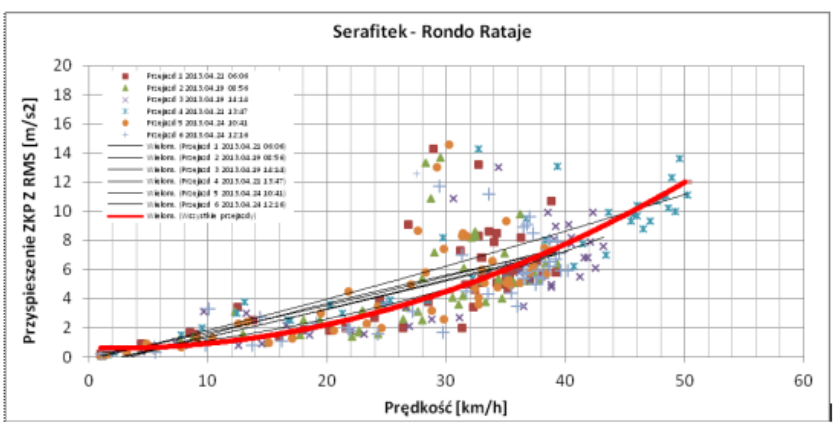

Rys. 7. Skuteczne wartości przyspieszeń w osi Z uzyskiwane na zestawie kołowym prawym (ZKP) w funkcji prędkości przejazdu ze zbiorczą linią trendu oraz dla pojedynczych przejazdów

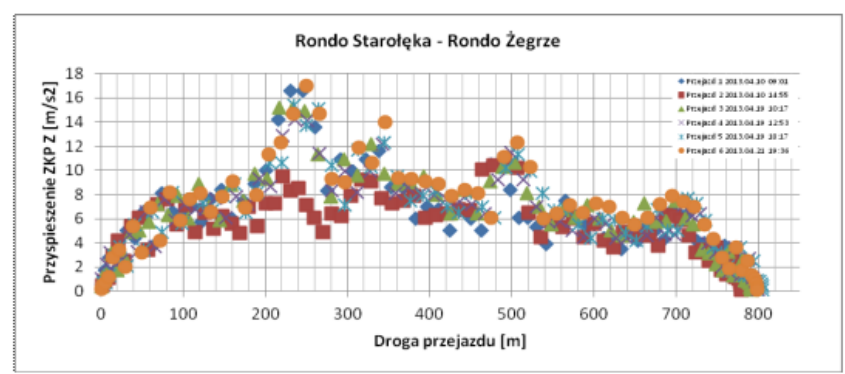

Rys. 8. Skuteczne wartości przyspieszeń w osi Z uzyskiwane na zestawie kołowym prawym (ZKP) na odcinku pomiarowym Rondo Starołęka - Rondo Żegrze wraz z prędkościami
Wielomianowe linie trendu wyraźnie pokazują wzrostową zależność przyspieszeń pionowych z czujnika zamontowanego po prawej stronie zestawu kołowego w funkcji prędkości tramwaju. Ukazano funkcję wielomianową dla wszystkich przejazdów, nałożoną na wyniki przyspieszeń poszczególnych przejazdów. Zaobserwowano znaczący wzrost powyżej prędkości $30 \mathrm{~km} / \mathrm{h}$, czyli maksymalnej dopuszczalnej prędkości tramwaju na wybranym odcinku.

$\mathrm{Na}$ rysunku nr 8 ukazano pionowe wartości przyspieszeń uzyskiwane na odcinku Rondo Starołęka - Rondo Żegrze w trakcie wszystkich przejazdów. Średnie arytmetyczne wartości przyspieszeń skutecznych $\mathrm{w}$ trakcie jazdy ze stałą prędkością utrzymują się na jednakowym poziomie $6-8 \mathrm{~m} / \mathrm{s}^{2}$. Wyróżniające się trzy chmury punktów na omawianym odcinku świadczą o występującej niwelacji toru oraz lokalnej zmianie stabilności podtorza wykazanych podczas przeprowadzonych oględzin toru.

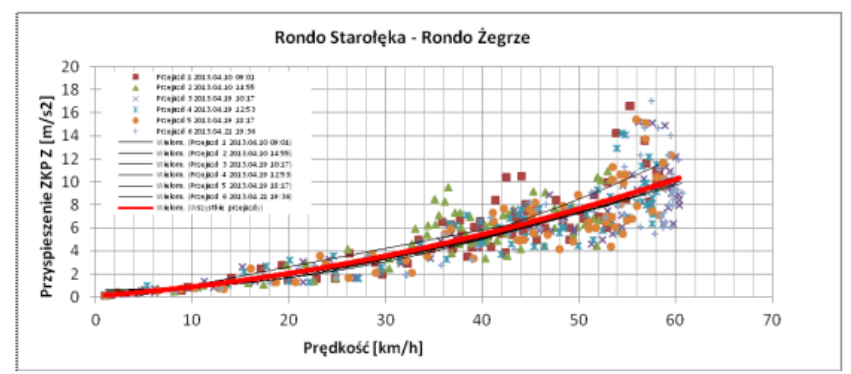

Rys. 9. Skuteczne wartości przyspieszeń w osi Z uzyskiwane na zestawie kołowym prawym (ZKP) w funkcji prędkości przejazdu z wykładniczymi liniami trendu na odcinku Rondo Starołęka Rondo Żegrze

Porównując skuteczne wartości przyspieszeń pionowych zmierzonych na łożysku osi atakującej $\mathrm{z}$ prędkościami tramwaju osiąganymi podczas poszczególnych przejazdów zauważono przyrost przyspieszeń razem z prędkością. Taka zależność wpływa na komfort oraz bezpieczeństwo jazdy. Co więcej zmierzone wartości przyspieszeń bez wątpienia przekładają się stan techniczny elementów tłumiących i układu biegowego. Dodatkowo thumienie zarejestrowanych wartości drgań przebiega w czasie wpływając na niekorzystne oddziaływanie pojazdu na tor, przyczyniając się do zwiększonego tempa degradacji toru.

\subsection{Drgania poprzeczne}

Kolejnymi zmierzonymi parametrami były przyspieszenia poprzeczne występujace, podobnie jak w przypadku przyspieszeń pionowych, na prawym zestawie kołowym pierwszej osi pierwszego wózka w kierunku jazdy. Rysunek nr 10 przedstawia rozkład zarejestrowanych przyspieszeń $\mathrm{w}$ funkcji przebytej drogi. Warto zwrócić uwagę na grupe punktów, podobnie jak w przypadku przyspieszeń w kierunku osi pionowej, w odległości ok. 50m od przystanku. 


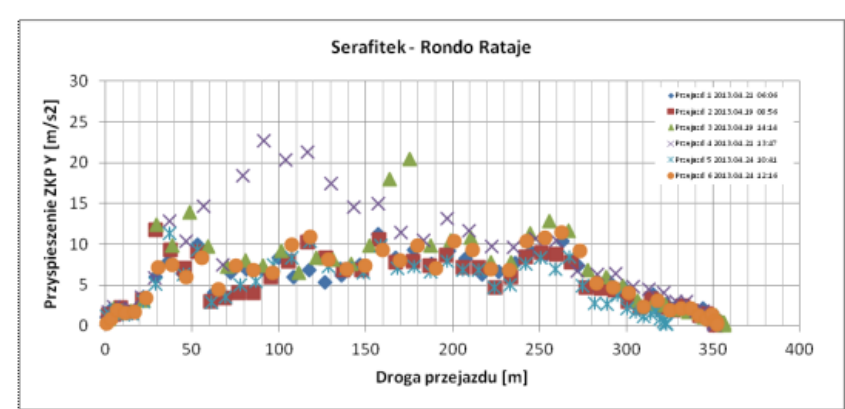

Rys. 10. Skuteczne wartości przyspieszeń w osi Y uzyskiwane na zestawie kołowym prawym (ZKP) w funkcji drogi

W przypadku porównania zmierzonych wartości przyspieszeń poprzecznych, w poszczególnych przejazdach, z uzyskiwaną na nich prędkością również zachodzi zależność większych przyspieszeń wraz ze wzrostem prędkości jazdy.

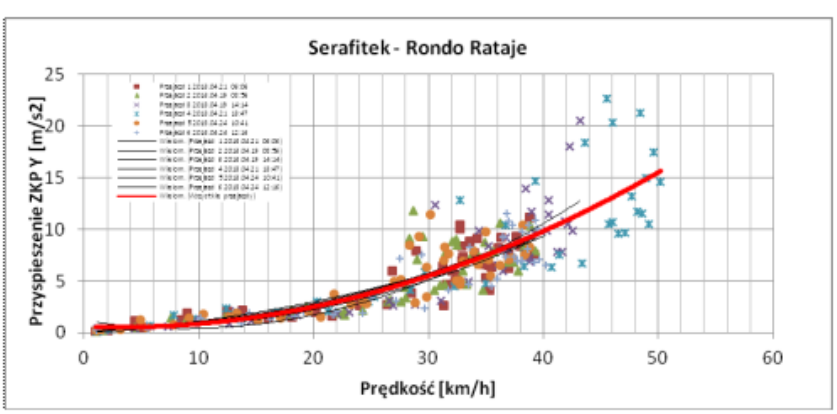

Rys. 11. Skuteczne wartości przyspieszeń w osi Y uzyskiwane na zestawie kołowym prawym (ZKP) na odcinku pomiarowym w

funkcji prędkości przy poszczególnych przejazdach wraz z wielomianowymi liniami trendu

W przypadku porównania zmierzonych wartości przyspieszeń poprzecznych, w poszczególnych przejazdach, z uzyskiwaną na nich prędkością również zachodzi zależność większych przyspieszeń wraz ze wzrostem prędkości jazdy.

Miejsca wyższych przyspieszeń poprzecznych zmierzonych (rys.12) na odcinku Rondo Starołęka Rondo Żegrze są porównywalne do miejsc przyspieszeń pionowych. Tutaj również pojawiają skoki, które pokrywają się z przyspieszeniem pionowym, zwłaszcza w okolicy 500 m odcinka pomiarowego. Świadczy to o miejscu w infrastrukturze, które jest w gorszym stanie technicznym. Potwierdzeniem tezy jest przeprowadzenie oględzin badanego odcinka. Dodatkowo wartości przyspieszeń poprzecznych osiagają ponad $20 \mathrm{~m} / \mathrm{s}^{2}$, przy maksymalnych przyspieszeniach pionowych $\left(17 \mathrm{~m} / \mathrm{s}^{2}\right)$.

Podobnie jak podczas przejazdów odcinkiem Serafitek - Rondo Rataje, tutaj również widoczne jest powiązanie pomiędzy prędkością a osiaganymi przyspieszeniami poprzecznymi. Wraz ze wzrostem prędkości tramwaju podczas wszystkich przejazdów widoczny jest także wzrost przyspieszeń poprzecznych. Zobrazowaniem tego jest nałożona wielomianowa linia trendu.

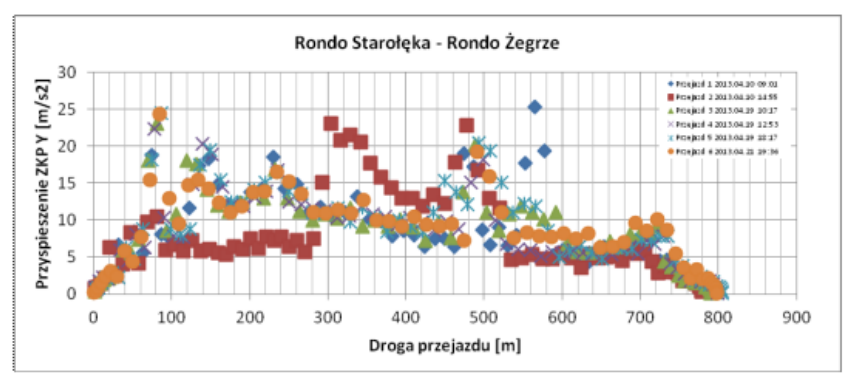

Rys. 12. Skuteczne wartości przyspieszeń w osi Y uzyskiwane na zestawie kołowym prawym (ZKP) w funkcji drogi i prędkości podczas przejazdów

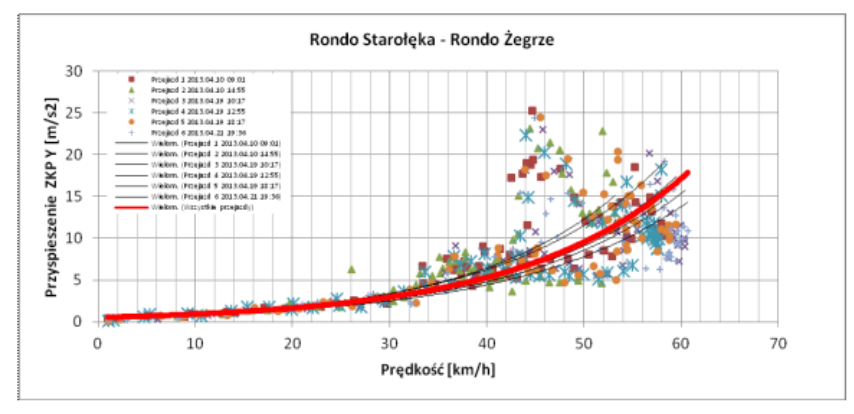

Rys. 13. Skuteczne wartości przyspieszeń w osi Y uzyskiwane na zestawie kołowym prawym (ZKP) na odcinku pomiarowym Rondo Starołęka - Rondo Żegrze w funkcji prędkości

\section{Eksperymentalna weryfikacja ograniczeń prędkości jazdy}

Metodyka przedstawionej przez autorów eksperymentalnej weryfikacji ograniczeń prędkości opiera się na konfrontacji zmierzonych wartości przyspieszeń pionowych i poprzecznych na zestawie kołowym podczas przejazdów na wybranych odcinkach o różnych ograniczeniach prędkości. Pierwszy odcinek posiada stałe ograniczenie prędkości do $30 \mathrm{~km} / \mathrm{h}$, drugi do $60 \mathrm{~km} / \mathrm{h}$. Podczas przejazdów na odcinku Serafitek - Rondo Rataje za każdym razem uzyskiwane prędkości były znacznie wyższe od zastosowanego przez zarządce infrastruktury ograniczenia. Powodem takiego zachowania przez osoby prowadzące tramwaj może być rutyna zdobyta podczas wcześniejszych przejazdów na danym odcinku, a także zamiar prowadzenia tramwaju zgodnie $\mathrm{z}$ rozkładem jazdy. W skrajnym przypadku może to być również celowe ignorowanie założonych ograniczeń. Warto zaznaczyć, iż każdy odcinek sieci tramwajowej z ograniczeniem prędkości innym, niż dopuszczają przepisy ruchu drogowego, jest klarownie oznakowany.

Skupiając się na pierwszym odcinku pomiarowym zauważono, że największe wartości przyspieszeń pionowych i poprzecznych występują w odległości ok. 50m od przystanku. Po dokonanej inspekcji fragmentu zauważono miejscową zmianę stabilności podtorza. Miejsce to występuje na łączeniu dylatacyjnym szyn, co dodatkowo zwiększa oddziaływanie pojazdu na tor. Na pozostałej części odcinka nie zmierzono wyższych wartości przyspieszeń. Można założyć, iż zarządca infrastruktury nałożył ograniczenie 
prędkości na cały odcinek sugerując się jedynie stanem technicznym jego fragmentu. Dodatkowo uzyskane wykładnicze linie trendu pokazały zależność pomiędzy prędkością a przyspieszeniem. Wraz ze wzrostem prędkości zwiększały się wartości rejestrowanych przyspieszeń, przekłada się to na komfort jazdy.

$\mathrm{Na}$ drugim odcinku pomiarowym Rondo Starołęka - Rondo Żegrze maksymalne osiagane prędkości podczas przejazdów mieściły się, w podniesionym, limicie prędkości. Zaobserwowano miejsca w których zarejestrowano większe wartości sygnałów. Po inspekcji omawianego odcinka spostrzeżono wyraźne nierówności toków szynowych, jak również zlokalizowano lokalną niestabilność podtorza. Dodatkowo zarejestrowano wyższe wartości średniokwadratowych przyspieszeń poprzecznych przy prędkości $45-50 \mathrm{~km} / \mathrm{h}$, niż w przypadku przejazdu z analogiczną prędkością na odcinku Serafitek - Rondo Rataje. Dowodzi to, iż ograniczenie do $60 \mathrm{~km} / \mathrm{h}$ jest za wysokie, a co za tym idzie niekorzystnie ono wpływa na komfort przejazdu dla pasażerów, stan techniczny pojazdu, infrastruktury oraz bezpieczeństwo jazdy.

\section{Wnioski}

W niniejszym artykule zaproponowano sposób weryfikacji nałożonych ograniczeń prędkości z jakościową oceną infrastruktury na podstawie wyników pomiarów pionowych i poprzecznych przyspieszeń skutecznych występujących na osi tramwaju w rzeczywistych warunkach eksploatacyjnych. Pomiarów dokonano na dwóch różnych odcinkach infrastruktury tramwajowej w Poznaniu. Pierwszy z nich posiadał stałe ograniczenie prędkości, jednak w trakcie wszystkich zebranych do badań przejazdów dochodziło do znacznego jej przekroczenia. W drugim przypadku podczas przejazdów nie dochodziło do przekroczenia ustalonego ograniczenia. Wartości przyspieszeń skutecznych w obydwu przypadkach były podobne. Dodatkowo wyznaczono wielomianowe linie trendu dla pojedynczych przejazdów oraz linie zbiorcze, obrazując trend pomiędzy prędkością przyspieszeniami. Weryfikacja wartości przyspieszeń pionowych i poprzecznych występujących w poziomie osi pojazdu $\mathrm{z}$ nałożonymi ograniczeniami prędkości jazdy może być wyznacznikiem bezpieczeństwa jazdy. Dodatkowo pokazano istotę nakładanych ograniczeń jazdy na całym wybranym odcinku. Badania wykazały, iż nałożone ograniczenie prędkości na odcinku Serafitek Rondo Rataje jest nieadekwatne do stanu technicznego toru. Kolejnym potwierdzeniem okazało się znaczne przekraczanie tego ograniczenia przez osoby prowadzące tramwaj. Przypuszczalnie skuteczniejszym rozwiązaniem byłoby ograniczenie prędkości tylko w wybranych miejscach badanego odcinka.
Dla przewoźnika lub zarządcy infrastruktury tak przedstawione wyniki moga być wyznacznikiem bezpieczeństwa jazdy oraz weryfikacji ograniczeń prędkości na odcinkach infrastruktury tramwajowej. Osoby odpowiedzialne za utrzymanie infrastruktury na podstawie przeanalizowanych wyników będą mogły dokonać weryfikacji ograniczeń prędkości na sieci tramwajowej, np. poprzez nałożenie ograniczeń tylko w wybranych punktach. Sugerowane rozwiązanie wpłynie na kongestię ruchu miejskiego oraz poprawi czas przejazdu. Dodatkowo weryfikacja pozwoli na dokładne określenie miejsc nierówności toru, co umożliwi szybką naprawę i zapobiegnie dalszej degradacji. Takie czynności będą doprowadzały do zmniejszenia nakładów finansowych związanych $\mathrm{z}$ utrzymaniem taboru i infrastruktury tramwajowej.

\section{Literatura}

[1] Firlik B., Chudzikiewicz A., Koncepcja systemu monitorowania stanu technicznego lekkich pojazdów szynowych, Czasopismo Techniczne Politechniki Krakowskiej Zeszyt 4, Rok 108, 2-M/2011

[2] Firlik B., Czechyra B., Symulacyjne podstawy metody monitorowania stanu technicznego toru tramwajowego, Prace naukowe Politechniki Warszawskiej, Zeszyt $84 / 2012$

[3] Chudzikiewicz A., Monitorowanie stanu uktadu dynamicznego pojazd szynowy - tor, Wyd. Wydziat Transportu Politechniki Warszawskiej, Warszawa 2012

[4] Chudzikiewicz A., Droździel J., Kisilowski J., Żochowski A., Modelowanie i analiza dynamiki układu mechanicznego tor-pojazd, Państwowe Wydawnictwa Naukowe, Warszawa 1982

[5] Esveld C., Modern Railway Track, Delft University of Technology, Delft 2001

[6] Iwnicki S., Handbook of Railway Vehicle Dynamics, CRC Press Taylor \& Francis Group, Boca Raton, FL 2006

[7] Uhl T., Hanc A., Dlugaszek D., Szromek A., Rzeczywiste obciqżenie tramwajów $w$ ruchu miejskim, Technika Transportu Szynowego 4/2004

[8] www.modertrans.pl [dostęp z dnia 29.04.2013r.]

[9] Materiaty wtasne MPK Poznań 